\title{
Hepatitis B Virus X Protein: A Key Regulator of the Virus Life Cycle
}

\author{
Julie Lucifora and Ulrike Protzer \\ Institute of Virology, Technische Universität \\ München / Helmholtz Zentrum München
}

Germany

\section{Introduction}

Hepatitis B virus (HBV) is one of the most important human pathogens. The outcome of $\mathrm{HBV}$ infection as well as the severity of $\mathrm{HBV}$-induced liver disease varies widely from one patient to another. In around $90-95 \%$ of adults, exposure to HBV leads to an acute infection which is rapidly cleared without long-term consequences. The remaining $5-10 \%$ fail to control viral infection that consequently evolves to chronicity. The rate of chronicity of viral infection is dramatically higher (up to 90\%) in neonates born from infected mothers, suggesting that infection around birth successfully induces peripheral tolerance to viral antigens which prevents clearance. About 2 billion humans have been infected by HBV worldwide and more than 350 million are chronic carriers. The latter have high risk to develop severe liver disease, including liver cirrhosis and hepatocellular carcinoma. Around 600,000 persons die each year due to consequences of hepatitis B infection. As HBV is a noncytopatic virus, HBV-related liver damage very likely results from the immune response against infected hepatocytes which is activated but not strong enough to clear infection.

Our knowledge of the molecular biology of HBV has increased considerably over the past decades, leading to the development of very effective prophylactic vaccines and to the development of direct antivirals active against HBV. Five nucleos(t)ide analogs are currently approved to treat chronic hepatitis B. Belonging to the same class of nucleosidic reverse transcriptase inhibitors, they specifically inhibit viral polymerase activity and thus suppress HBV replication, significantly improving liver histology and the clinical outcomes of the disease after one year of treatment (Liaw et al., 2004). Unfortunately, nucleos(t)ide analogs act at a late stage in the HBV life cycle (i.e. maturation of newly formed viral capsids by reverse transcription of pregenomic RNA) and do neither prevent formation and nuclear establishment nor activity of the HBV transcription template, the so called HBV covalently closed circular (ccc) DNA.

Long-term treatments with nucleos(t)ide analogs are thus necessary to cure HBV infected cells and unfortunately lead to the selection of HBV drug-resistant strains (Zoulim, 2006). Even very effective antivirals such as Tenofovir lead to HBsAg seroconversion in only 3 to $8 \%$ of patients over three years (Heathcote et al., 2011; van Bommel et al., 2010). Pegylated (PEG)-IFN- $\alpha$ is an established treatment alternative and acts as an antiviral but also enhances the host's immune defense. However, only $30 \%$ of PEG-IFN- $\alpha$-treated patients 
achieve a sustained antiviral response (Karayiannis, 2003), and only about 8-10\% of patients clear the virus (Marcellin et al., 2009) with slightly increasing rates during long-term followup (Moucari et al., 2009). New therapeutic approaches that target other viral proteins, besides viral polymerase, are needed to decrease viral drug resistance and improve treatments against $\mathrm{HBV}$.

This chapter will particularly focus on the hepatitis B virus $\mathrm{X}$ protein (HBx) that is essential to initiate and maintain transcription of HBV RNA from nuclear cccDNA and thus is a key regulator of the virus life cycle. Due to its central role, $\mathrm{HBx}$ represents a very promising new target for antiviral strategies against HBV.

\subsection{Hepatitis B virus structure and proteins}

HBV belongs to the family hepadnaviridae. It is a small, enveloped DNA virus that replicates via reverse transcription of an RNA intermediate. HBV virions, also called Dane particles, are spherical lipid-containing structures with a diameter of $\sim 42 \mathrm{~nm}$ (Fig. 1). The inner shell

A

\begin{tabular}{|l|l|}
\hline \multicolumn{2}{|c|}{ HBV proteins } \\
\hline $\mathrm{S}$ & small surface protein \\
\hline $\mathrm{M}$ & middle surface protein \\
\hline $\mathrm{L}$ & large surface protein \\
\hline core & capsid protein \\
\hline $\mathrm{HBeAg}$ & secreted e antigen \\
\hline pol & polymerase \\
\hline $\mathrm{HBX}$ & X protein (non-secreted) \\
\hline
\end{tabular}

B

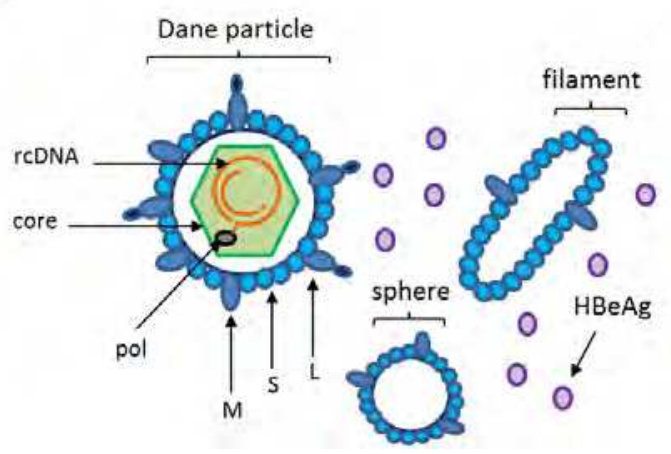

Fig. 1. HBV proteins and virion structure. (A) List of all HBV proteins. (B) Viral particles present in the serum of $\mathrm{HBV}$-infected patients are schematically represented. The so-called "Dane particles" are fully infectious viral particles containing the HBV capsid and one rcDNA genome copy with the viral polymerase attached. Subviral particles of spherical or filamentous shapes consist of empty viral envelopes. Together, Dane particles, spheres, and filaments are recognized as HBsAg. The precore protein is secreted as HBeAg.

of the virus consists of an icosahedral capsid, which is assembled from 180 or 240 subunits of the core protein. The capsid is covered by a lipid bilayer membrane densly packed with the three envelope proteins, large (L), middle (M), and predominantly small (S) protein, and is acquired by budding into the endoplasmic reticulum. They are translated from individual start codons but share the open reading frame and the same C-terminal amino acids, called the $S$ domain. As a consequence, the $M$ protein shares the $S$ and has an extra $\mathrm{N}$-terminal domain called preS2, and the L protein encompasses the $S$ and two extra domains: preS2 and preS1. Capsids contain a single copy of the HBV genome consisting of a 3.2-kb partially double-stranded relaxed circular ( $\mathrm{rc}$ ) DNA molecule. The viral polymerase serves as a protein primer and remains covalently linked to the $5^{\prime}$ end of the complete strand, also called viral (-) strand DNA of the rcDNA after reverse transcription. Besides virions, HBV infection leads to secretion of huge amounts of subviral particles, which consist of empty 
viral envelopes with filamentous or spherical shapes (Fig. 1) containing mainly S and little L protein. Subviral particles are the most abundant HBV structures released into the bloodstream, are commonly defined as hepatitis B surface (HBs) antigen and are thought to facilitate virus spread and persistence in the host by adsorbing virus-neutralizing antibodies and tolerizing $\mathrm{T}$ cell responses.

In addition to polymerase and the structural proteins, the HBV genome also encodes for two non-structural proteins, which have less well-defined functions. Secreted HBeAg may have immunoregulatory functions (Bertoletti \& Gehring, 2006; Chen et al., 2005; Chen et al., 2004; Visvanathan et al., 2007), whereas HBx seems to have multiple key functions as it will be detailed later.

\subsection{Overview of the hepatitis B virus life cycle}

A schematic overview of the HBV life cycle is depicted below in Fig. 2. HBV infection is restricted to hepatocytes. HBV entry into these cells is thought to be a multistep process. Virions are first trapped at the surface of the cell by heparan sulfate proteoglycans (Schulze et al., 2007) and then bind to a receptor allowing uptake into the cells via an endocytosis process (Kott, 2010; Leistner et al., 2008). So far, this cellular receptor as not been identified. Proteolytic cleavage of the surface protein occurs within the endosomal compartment, probably resulting in a conformational change that exposes some translocation motifs at the surface of the viral particle allowing fusion of viral and cellular membranes and release of the capsid into the cytosol (Stoeckl et al., 2006).

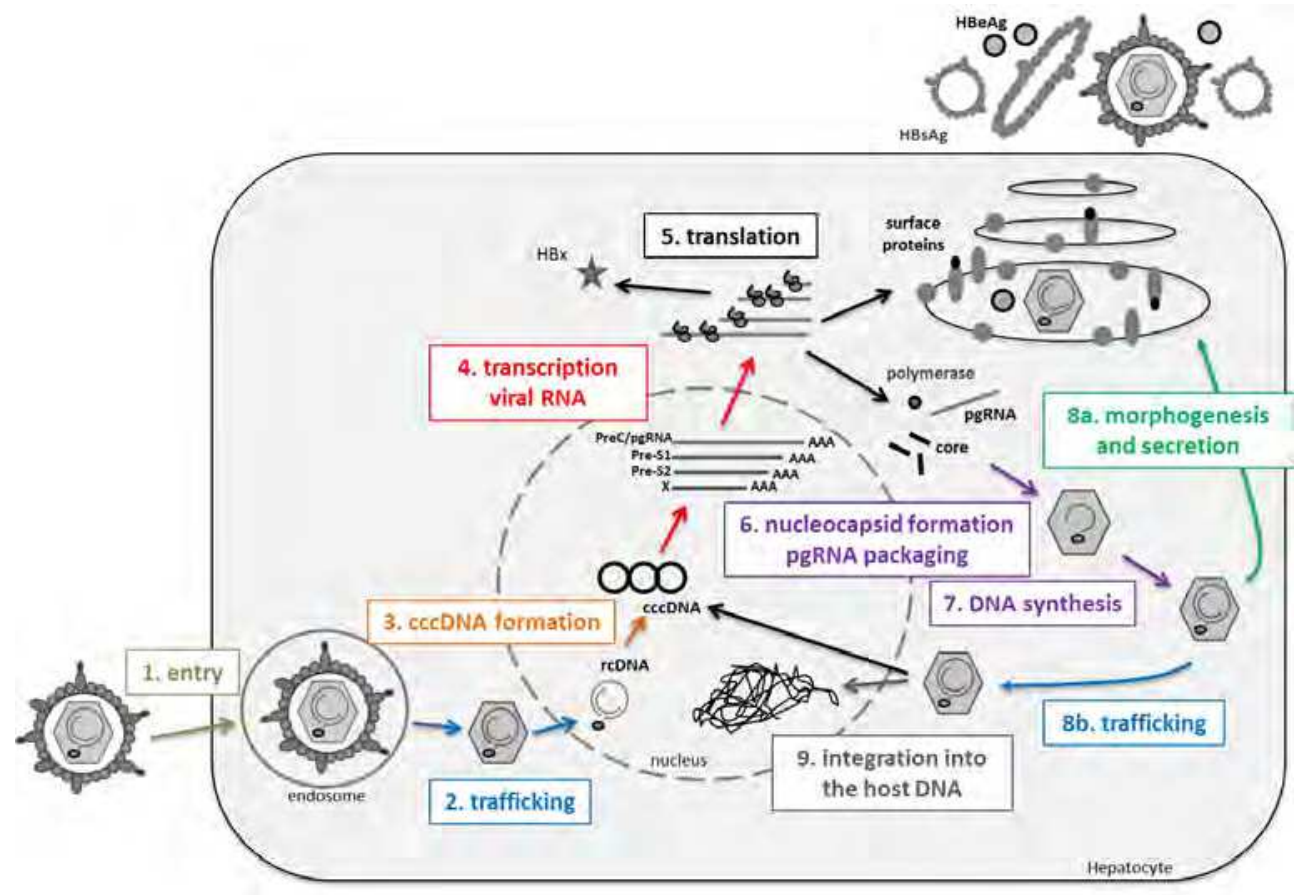

Fig. 2. Schematic overview of the HBV life cycle. 
The naked capsid is then directed towards the nucleus, and the HBV genome is translocated to the nucleus (Rabe et al., 2006). In the nucleus, the rcDNA genome is converted by cellular enzymes into a covalently closed circular DNA (cccDNA), the episomal persistance form of the virus serving as transcription template. The $3.5 \mathrm{~kb}$ RNA species serves as pregenomic RNA (pgRNA) and as messenger RNAs for the synthesis of polymerase and core proteins as well as HBeAg. The 2.1 and $2.4 \mathrm{~kb}$ subgenomic RNAs encode for the three viral envelope proteins, a small $0.7 \mathrm{kbRNA}$ for the HBx. The pgRNA is exported in an unspliced form, encapisidated together with the viral polymerase and used as a template for reverse transcription. The capsid spontaneously self-assembles from core dimers present in the cytoplasm (Zlotnick et al., 1999) due to the nucleic acid-binding domain of the core protein. Specific packaging of pgRNA into the capsid is mediated by binding of the primer region of the viral polymerase to the $\varepsilon$ stem-loop in the 5' region of pgRNA (Hirsch et al., 1990; JunkerNiepmann et al., 1990; Knaus \& Nassal, 1993; Nassal, 1992; Porterfield et al., 2010). The pgRNA is then reverse transcribed by the reverse transcriptase domain of the polymerase within the capsid in the cytoplasm of the infected cell. Upon minus and then plus strand DNA synthesis the capsid matures and can be enveloped or reimported into the nucleus to fill up a cccDNA pool.

HBV budding has been shown to be strictly dependent on the L protein (Bruss \& Vieluf, 1995): when the ratio between $L$ proteins and nucleocapsids is not optimal, the latter are preferentially targeted to the nucleus to amplify the cccDNA pool (Summers et al., 1990). Whether HBV virions bud into the endoplasmic reticulum or late endosomes or multivesicular bodies, before they exit the cell via the exosome pathway, is not entirely clear (Patient et al., 2009). As an alternative and although it is not essential for the HBV life cycle, the viral genome may also integrate into the host genome using cellular enzymes such as topoisomerase I (Wang \& Rogler, 1991).

\subsection{General features about HBx}

HBx is translated from a small subgenomic RNA controlled by the HBx promoter (Guo et al., 1991). Alternatively, HBx may be produced form a very long RNA (3.9 kb) containing all the HBV open reading frames (ORF) (Doitsh \& Shaul, 2003). The ORF was originally designated $\mathrm{X}$ because of the lack of homology with known sequences. HBx is a protein composed of 154 amino acid residues with a molecular mass of around $17.5 \mathrm{kDa}$. Due to the lack of successful crystallography analyses, little is known about its three dimensional structure. Posttranscriptional modifications of $\mathrm{HBx}$ such as phosphorylation or acetylation have been described (Schek et al., 1991; Urban et al., 1997), the latest being observed only in insect cells. But the significance of such modifications for the described activities of HBx has not been assessed yet.

Cellular localization of $\mathrm{HBx}$ has been debated over the years. Indeed, some studies show a cytoplasmic localization (Dandri et al., 1996; Doria et al., 1995; Sirma et al., 1998; Su et al., 1998), whereas others find that HBx is preferentially nuclear (Weil et al., 1999), or present both in the cytoplasm and the nucleus (Hoare et al., 2001; Schek et al., 1991). It appears that $\mathrm{HBx}$ expressed at very low level is predominantly nuclear, whereas high levels of HBx lead to cytoplasmic accumulation (Cha et al., 2009; Henkler et al., 2001). Discrepancies regarding $\mathrm{HBx}$ localization could thus be attributed to variations of HBx expression levels according to the models used for the experiments in the different studies. 
Cellular localization of HBx was shown to influence the half-life of the protein. Indeed, the pool of HBx associated with the cytoskeleton and nuclear framework has a longer half-life (around $3 \mathrm{~h}$ ) than the one associated with the cytosolic fraction (15 to $20 \mathrm{~min}$ ) (Dandri et al., 1998; Schek et al., 1991). Both ubiquitin-dependent and ubiquitin-independent mechanisms have been involved in HBx turnover (Hu et al., 1999; Kim et al., 2008).

\section{Importance of $\mathrm{HBx}$ for $\mathrm{HBV}$ infection}

In the woodchuck model of HBV infection, it was shown that the woodchuck hepatitis virus (WHV) X protein (WHx) is essential for the establishment of viral infection in vivo (Chen et al., 1993; Zoulim et al., 1994). Indeed, injection of WHV wild type genomes into the liver of woodchuck lead to WHV infection of all the tested animals whereas no replication was observed when genomes deficient for WHx expression were injected (Chen et al., 1993; Zoulim et al., 1994). Few years later, it was observed that animals injected with WHxdefective mutants eventually developed a low viremia after an extended period of time (Zhang et al., 2001), suggesting that this WHx-defective mutant were not completely defective but largely attenuated for $\mathrm{HBV}$ replication in vivo. Accordingly, genotypic reversions to wild type WHV were observed in all animals inoculated with WHx-deficient mutants (Zhang et al., 2001). Taken together, these results point out the importance of WHx for a productive and long lasting WHV infection.

In addition, it was shown that HBx-deficient HBV genomes are somewhat compromised for HBV replication using HBV hydrodynamically-injected mice (Keasler et al., 2007; 2009) or cell culture models (Belloni et al., 2009; Blum et al., 1992; Keasler et al., 2007; Leupin et al., 2005). Surprisingly, the absence of $\mathrm{HBx}$ had no effect on HBV replication in human hepatoma Huh7 cell lines, but impaired replication in HepG2 cells (Blum et al., 1992; Keasler et al., 2007; 2009; Leupin et al., 2005). Accordingly, data in HBV transgenic mice are contradictory with some mouse lines showing reduced replication (Xu et al., 2002), whereas others replicate HBV to high levels (Dumortier et al., 2005).

The importance of HBx in the context of human HBV infection was demonstrated very recently using human hepatocyte chimeric mice and relevant cellular models of HBV infection. Indeed, it was observed that mice injected with $\mathrm{HBx}$ deficient HBV virus developed measurable viremia only in HBx-expressing livers (Tsuge et al., 2010). Moreover, using primary human hepatocyte (Schulze-Bergkamen et al., 2003) and differentiated HepaRG cells (Gripon et al., 2002), that are the only two models of HBV infection in vitro, we recently demonstrated that $\mathrm{HBx}$ is essential to initiate and constantly required to maintain productive HBV infection (Lucifora et al., 2011).

This latter study highlighted the importance of performing experiments in relevant in vitro and in vivo models. Indeed, results obtained with in vitro HBV infection models (i.e. primary human hepatocyte and differentiated HepaRG cells) (Lucifora et al., 2011) support and explain the above mentioned observations obtained in mouse livers (Keasler et al., 2007; Tsuge et al.). However, they differ from results obtained by transfection of linearized HBV genomes into transformed cells (Blum et al., 1992; Leupin et al., 2005) especially when HBx is overexpressed to non-physiological levels. Solving this apparent discrepancy, we were able to demonstrate that $\mathrm{HBx}$ is essential when HBV transcription is initiated from its natural transcription circular template (cccDNA) but not from a linearized 1.3-fold genome length 
HBV genome (Lucifora et al., 2011) containing a duplicate copy of the HBx open reading frame 5' of the HBV genome (Reifenberg et al., 2002; Sprinzl et al., 2001; Zhang et al., 2004) irrespective of whether the linearized HBV genome is integrated or episomal.

\section{Functions of HBx in the HBV life cycle}

Different functions have been attributed to HBx regarding HBV life cycle (Fig. 3).

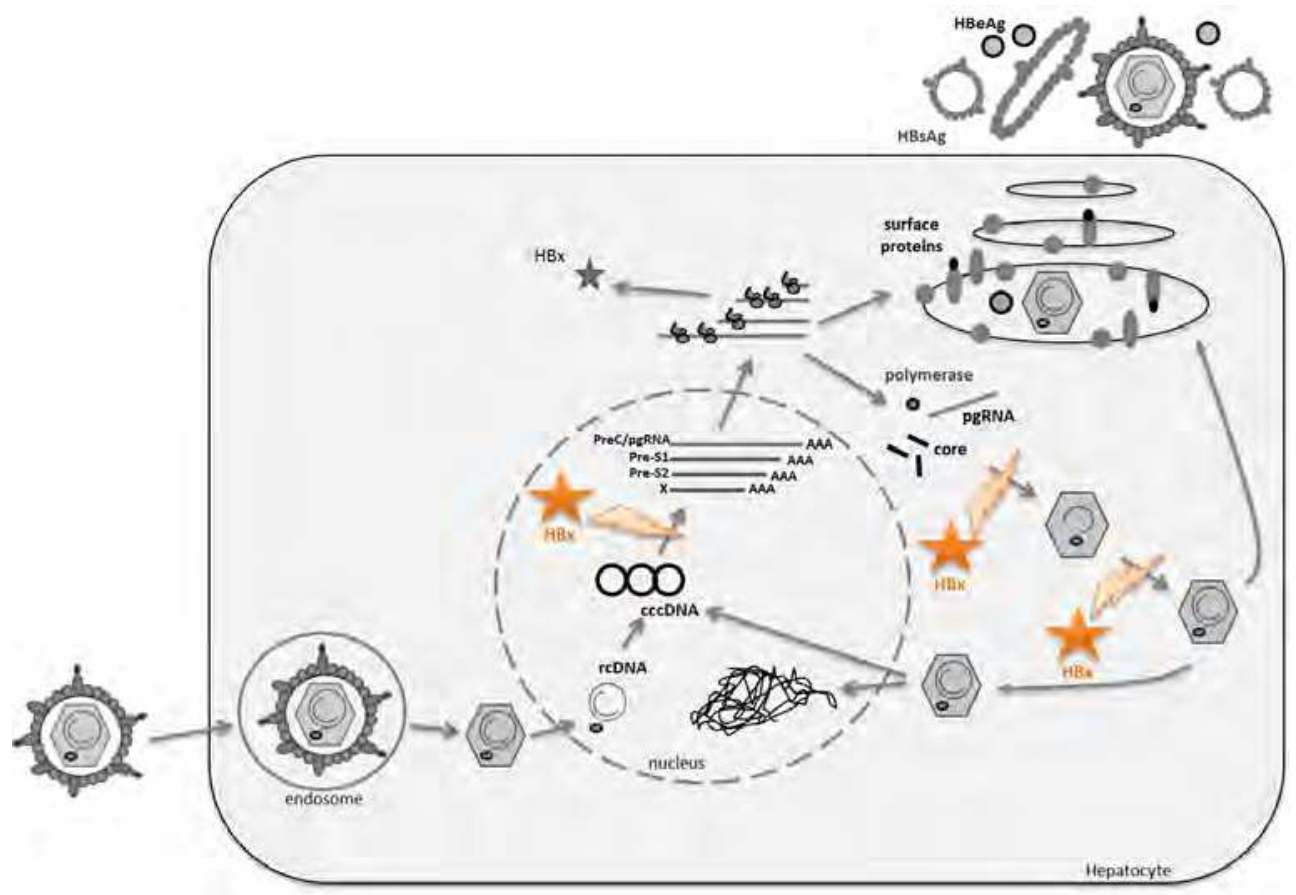

Fig. 3. Functions attributed to HBx in the HBV life cycle. HBx is an important regulator of HBV transcription. Moreover, it might also enhance pgRNA encapsidation and viral polymerase activity.

Several studies have shown that HBx can stimulate HBV replication by activating viral transcription (Cha et al., 2009; Leupin et al., 2005; Tang et al., 2005; Zhang et al., 2004; Zhang et al., 2001) or enhancing viral polymerase activity via calcium signalling pathways (Bouchard et al., 2003; Bouchard et al., 2001; Klein et al., 1999). HBx was also proposed to enhance pgRNA encapsidation by increasing phosphorylation of the viral core protein (Melegari et al., 2005) although these results were recently challenged (Cha et al., 2009).

We recently showed that HBx does not determine the ability of HBV to enter the host cell or to deposit functional nuclear cccDNA but is essential for viral transcription from its natural transcription template, the nuclear HBV cccDNA (Lucifora et al., 2011). Indeed primary human hepatocytes or differentiated HepaRG cells inoculated with different HBV virions, $\mathrm{HBV}(\mathrm{wt})$ and $\mathrm{HBV}(\mathrm{x}-)$ established comparable amounts of nuclear transcription templates but in contrast to $\mathrm{HBV}(w \mathrm{t})$, transcription of $\mathrm{HBV}$ RNAs and expression of HBV proteins was 
dramatically impaired in cells inoculated with $\operatorname{HBV}(x-)$ (Lucifora et al., 2011). Transcomplementation of $\mathrm{HBx}$ in $\mathrm{HBV}(\mathrm{x}-)$-infected cells was able to rescue $\mathrm{HBV}$ transcription, antigen secretion and replication even weeks after infection. This demonstrated that $\mathrm{HBx}-$ deficient cccDNA is fully functional and very stable, but also that HBx is necessary to initiate and maintain HBV replication after infection of human hepatocytes (Lucifora et al., 2011).

Our results complement a series of data indicating that $\mathrm{HBx}$ has an important role in epigenetic regulation of HBV transcription from cccDNA. Indeed, cccDNA can persist in the cell nucleus as a stable chromatin-like episome (Bock et al., 2001) and was shown to be submitted to epigenetic modifications such $\mathrm{H} 3$ and $\mathrm{H} 4$ histone acetylations when HBV was actively replicating (Pollicino et al., 2006). Besides cellular proteins such as histone acetyltransferases and histone deacetylases, $\mathrm{HBx}$ is also recruited onto the cccDNA with a kinetic paralleling HBV replication (Belloni et al., 2009). Moreover, in the absence of HBx, the acetylation of cccDNA-bound histones H4 was significantly reduced (Belloni et al., 2009; Lucifora et al., 2011), the recruitment of the histone acetyltransferase p300 was severely impaired whereas the recruitment of the histone deacetylases hSirt1 and HDAC1 was increased and occured at earlier times (Belloni et al., 2009).

The differences mentioned above in the regulation of viral transcription from cccDNA and from linearized HBV genomes (which are present in all plasmid constructs and stable cell lines) may help to explain, why the function of HBx was evaluated differently when different HBV constructs were used (Blum et al., 1992; Bouchard et al., 2001; Melegari et al., 2005; Reifenberg et al., 2002; Sprinzl et al., 2001). However, transcriptional regulation by HBx may also depend on the cell type used, since transformed cells may lack or antagonize cellular proteins with a positive or negative influence on viral transcription.

Although $\mathrm{HBx}$ is essential for the expression of the other viral proteins, no evidence for packaging of HBx into the HBV particle has been provided (Lucifora et al., 2011). Therefore, the question of how HBx expression itself is induced and regulated remains open. Different hypotheses may apply. First, HBx mRNA transcription may be specifically regulated and may occur before transcription of the other HBV RNAs. This implies the question whether an early-late shift exists for HBV such as for most other viruses - with HBx as an early protein essential for expression of the remaining (late) proteins. Some studies performed in transfection models support this assumption (Doitsh \& Shaul, 2004; Wu et al., 1991) suggesting that HBV may express its gene products in a defined order.

A second hypothesis does not require the presence of $\mathrm{HBx}$ in the early phase of $\mathrm{HBV}$ infection. If $\mathrm{HBV}$ transcription from cccDNA starts shortly after infection independent from $\mathrm{HBx}$, this would lead to the production of all the HBV proteins including HBx. Subsequent activation of a cellular response controlling HBV replication and/or binding of cellular restriction factor(s) could - in the absence of HBx - inhibit HBV transcription from cccDNA. $\mathrm{HBx}$ would here be essential to prevent inhibition of HBV transcription by cell-intrinsic mechanisms. Since HBx would have to up-regulate its own expression in a "positive feedback loop", this would explain why a lag phase is observed before HBV replication starts after infection in all the HBV infection models (Dandri et al., 2005; Gripon et al., 1988; Gripon et al., 2002; Walter et al., 1996; Wieland et al., 2004). Whether one of these hypotheses or a third one explains dependency of $\mathrm{HBV}$ replication on $\mathrm{HBx}$ is currently investigated. 


\section{HBx influences many cellular processes}

Besides its role in HBV replication, thousands of publications showed that HBx interacts with various cellular partners and modifies many cellular processes including transcription, cell cycle progression, DNA damage repair, apoptosis and carcinogenesis (for review, see Benhenda et al., 2009; Bouchard \& Schneider, 2004; Wei et al., 2010). As we will show with the following examples, interactions of $\mathrm{HBx}$ with cellular components may represent an attempt of the virus to manipulate the cellular context in order to stimulate virus replication and spread.

HBx has been described to be a weak transactivator able to activate HBV promoters and enhancers as well as many different cellular promoters (Yen, 1996). Whereas, HBx does not seem to directly bind to DNA, its transactivation activity was reported to occur via several DNA binding sites such as NF-KB, AP-1, c-EBP, ATF/CREB, NF-AT, SP1 etc. (for review, see Quasdorff \& Protzer, 2010; Yen, 1996).

Different studies have shown an interplay between $\mathrm{HBx}$ and apoptosis pathways. Indeed, $\mathrm{HBx}$ could sensitize the cells to apoptotic signals such as treatments with TNF or doxorubicin, oxidative stress or growth factor deprivation (for review, see Benhenda et al., 2009; Bouchard \& Schneider, 2004; Wei et al., 2010). This may promote hepatocyte regeneration, thus providing a larger reservoir of cells for infection. However $\mathrm{HBx}$ may also prevent apoptosis induction since it rapidly blocks spread of HBV progeny (Arzberger et al., 2010).

HBx may also be involved in cell cycle regulation but its relative influence seems to differ according to the models used (for review, see Benhenda et al., 2009; Bouchard \& Schneider, 2004; Wei et al., 2010). For example, using primary rat hepatocytes, it was recently demonstrated that $\mathrm{HBx}$ induces normally quiescent hepatocytes to enter the $\mathrm{G}_{1}$ phase of the cell cycle and that this calcium-dependent $\mathrm{HBx}$ activity is required for HBV replication (Gearhart \& Bouchard, 2010). While this effect of HBx on cell cycle progression can probably lead to carcinogenesis and thus become deleterious for the host, it is believed that it might be important for the virus to induce expansion of available deoxynucleoside triphosphate pools within the cells which it needs for replication (Bouchard et al., 2003). Indeed, using HepG2 cells, it was reported that $\mathrm{HBx}$ is sufficient for the induction of the R2 subunit of the ribonucleotide reductase (RNR) (Cohen et al., 2010). RNR is the key enzyme responsible for de novo dNTP synthesis and is composed of R1 and R2 subunits (Nordlund \& Reichard, 2006). While the R1 subunit is expressed in quiescent cells, the R2 subunit expression is silenced (Chabes et al., 2003). As a consequence of induction of R2 by HBx, the dNTP pool for effective viral production was increased without affecting cell cycle progression (Cohen et al., 2010).

Different groups using different models showed that HBx may localize and interact with the proteasome components thereby influencing proteasome subunit composition (Chen et al., 2001; Fischer et al., 1995; Hu et al., 1999; Zhang et al., 2000). Moreover proteasome inhibition was shown to enhance HBV replication in cell culture and in mice models (Zhang et al., 2004; Zhang et al., 2010). Indeed, in the presence of proteasome inhibitors, the replication of the wildtype virus was not affected, while the replication of the HBx-negative virus was enhanced and restored to the wild-type level (Zhang et al., 2004; Zhang et al., 2010). Thus HBx may functions through the inhibition of proteasome activities to enhance HBV replication.

Finally, several studies have pointed out an interaction between HBx and the DNA repair protein DDB1 that would be essential for HBV infection (Leupin et al., 2005; Sitterlin et al., 2000). However, the exact mechanism by which this interaction may help the virus is still debated. 
Of note, most of the interactions of HBx with cellular processes have been studied in many different models often leading to significant overexpression of $\mathrm{HBx}$ and outside the context of HBV infection. Thus, it remains important to determine whether similar manipulations of the cellular machinery by HBx would also occur in the context of an authentic HBV infection.

\section{Conclusion}

Numerous and significant studies have been performed over the past decades to analyze the role of HBx in the HBV life cycle. Many data were generated by using different in vivo and in vitro models, but contradictory results describing $\mathrm{HBx}$ function were obtained. The importance and the precise role of $\mathrm{HBx}$ on HBV life cycle thus remained unclear until recently models allowing an authentic HBV infection were used (Lucifora et al., 2011; Tsuge et al., 2010). Most studies, including the most recent, agree that HBx is essential for HBV infection. Besides its importance for HBV transcription from nuclear HBV cccDNA, it may also influence downstream steps of the HBV life cycle possibly by manipulating different cellular machineries. Unfortunately, in the long-term, these manipulations are probably leading to hepatocellular de-differentiation and progression towards liver cancer. As HBx plays a central role in HBV infection and cannot avoid influencing many cellular processes related to disease progression, it may be a very interesting target for new therapies against chronic hepatitis B. Targeting HBx may prevent both: viral replication as well as liver tissue damage and carcinogenesis.

\section{Acknowledgement}

Julie Lucifora holds a stipend from the European Association for the Study of Liver disease (EASL): "Sheila Sherlock EASL Post-Doc Fellowship".

\section{References}

Arzberger, S., Hosel, M. \& Protzer, U. (2010). Apoptosis of hepatitis B virus-infected hepatocytes prevents release of infectious virus. J Virol 84, 11994-12001.

Belloni, L., Pollicino, T., De Nicola, F., Guerrieri, F., Raffa, G., Fanciulli, M., Raimondo, G. \& Levrero, M. (2009). Nuclear HBx binds the HBV minichromosome and modifies the epigenetic regulation of cccDNA function. Proc Natl Acad Sci U S A 106, 19975-19979.

Benhenda, S., Cougot, D., Buendia, M. A. \& Neuveut, C. (2009). Hepatitis B virus X protein molecular functions and its role in virus life cycle and pathogenesis. Adv Cancer Res 103, 75-109.

Bertoletti, A. \& Gehring, A. J. (2006). The immune response during hepatitis B virus infection. J Gen Virol 87, 1439-1449.

Blum, H. E., Zhang, Z. S., Galun, E., von Weizsacker, F., Garner, B., Liang, T. J. \& Wands, J. R. (1992). Hepatitis B virus $X$ protein is not central to the viral life cycle in vitro. J Virol 66, 1223-1227.

Bock, C. T., Schwinn, S., Locarnini, S., Fyfe, J., Manns, M. P., Trautwein, C. \& Zentgraf, H. (2001). Structural organization of the hepatitis B virus minichromosome. J Mol Biol 307, 183-196.

Bouchard, M. J., Puro, R. J., Wang, L. \& Schneider, R. J. (2003). Activation and inhibition of cellular calcium and tyrosine kinase signaling pathways identify targets of the HBx protein involved in hepatitis B virus replication. J Virol 77, 7713-7719. 
Bouchard, M. J. \& Schneider, R. J. (2004). The enigmatic X gene of hepatitis B virus. J Virol $78,12725-12734$.

Bouchard, M. J., Wang, L. H. \& Schneider, R. J. (2001). Calcium signaling by HBx protein in hepatitis B virus DNA replication. Science 294, 2376-2378.

Bruss, V. \& Vieluf, K. (1995). Functions of the internal pre-S domain of the large surface protein in hepatitis B virus particle morphogenesis. J Virol 69, 6652-6657.

Cha, M. Y., Ryu, D. K., Jung, H. S., Chang, H. E. \& Ryu, W. S. (2009). Stimulation of hepatitis $\mathrm{B}$ virus genome replication by $\mathrm{HBx}$ is linked to both nuclear and cytoplasmic $\mathrm{HBx}$ expression. J Gen Virol 90, 978-986.

Chabes, A. L., Pfleger, C. M., Kirschner, M. W. \& Thelander, L. (2003). Mouse ribonucleotide reductase R2 protein: a new target for anaphase-promoting complex-Cdh1mediated proteolysis. Proc Natl Acad Sci U S A 100, 3925-3929.

Chen, H. S., Kaneko, S., Girones, R., Anderson, R. W., Hornbuckle, W. E., Tennant, B. C., Cote, P. J., Gerin, J. L., Purcell, R. H. \& Miller, R. H. (1993). The woodchuck hepatitis virus $X$ gene is important for establishment of virus infection in woodchucks. J Virol 67, 1218-1226.

Chen, M., Sallberg, M., Hughes, J., Jones, J., Guidotti, L. G., Chisari, F. V., Billaud, J. N. \& Milich, D. R. (2005). Immune tolerance split between hepatitis B virus precore and core proteins. J Virol 79, 3016-3027.

Chen, M. T., Billaud, J. N., Sallberg, M., Guidotti, L. G., Chisari, F. V., Jones, J., Hughes, J. \& Milich, D. R. (2004). A function of the hepatitis B virus precore protein is to regulate the immune response to the core antigen. Proc Natl Acad Sci U S A 101, 14913-14918.

Chen, W. N., Oon, C. J. \& Goo, K. S. (2001). Hepatitis B virus X protein in the proteasome of mammalian cells: defining the targeting domain. Mol Biol Rep 28, 31-34.

Cohen, D., Adamovich, Y., Reuven, N. \& Shaul, Y. (2010). Hepatitis B virus activates deoxynucleotide synthesis in nondividing hepatocytes by targeting the R2 gene. Hepatology 51, 1538-1546.

Dandri, M., Burda, M. R., Zuckerman, D. M., Wursthorn, K., Matschl, U., Pollok, J. M., Rogiers, X., Gocht, A., Kock, J., Blum, H. E., von Weizsacker, F. \& Petersen, J. (2005). Chronic infection with hepatitis B viruses and antiviral drug evaluation in uPA mice after liver repopulation with tupaia hepatocytes. J Hepatol 42, 54-60.

Dandri, M., Petersen, J., Stockert, R. J., Harris, T. M. \& Rogler, C. E. (1998). Metabolic labeling of woodchuck hepatitis B virus $\mathrm{X}$ protein in naturally infected hepatocytes reveals a bimodal half-life and association with the nuclear framework. J Virol 72, 9359-9364.

Dandri, M., Schirmacher, P. \& Rogler, C. E. (1996). Woodchuck hepatitis virus X protein is present in chronically infected woodchuck liver and woodchuck hepatocellular carcinomas which are permissive for viral replication. J Virol 70, 5246-5254.

Doitsh, G. \& Shaul, Y. (2003). A long HBV transcript encoding pX is inefficiently exported from the nucleus. Virology 309, 339-349.

Doitsh, G. \& Shaul, Y. (2004). Enhancer I predominance in hepatitis B virus gene expression. Mol Cell Biol 24, 1799-1808.

Doria, M., Klein, N., Lucito, R. \& Schneider, R. J. (1995). The hepatitis B virus HBx protein is a dual specificity cytoplasmic activator of Ras and nuclear activator of transcription factors. Embo J 14, 4747-4757.

Dumortier, J., Schonig, K., Oberwinkler, H., Low, R., Giese, T., Bujard, H., Schirmacher, P. \& Protzer, U. (2005). Liver-specific expression of interferon gamma following 
adenoviral gene transfer controls hepatitis B virus replication in mice. Gene Ther 12, 668-677.

Fischer, M., Runkel, L. \& Schaller, H. (1995). HBx protein of hepatitis B virus interacts with the C-terminal portion of a novel human proteasome alpha-subunit. Virus Genes 10, 99-102.

Gearhart, T. L. \& Bouchard, M. J. (2010). The hepatitis B virus X protein modulates hepatocyte proliferation pathways to stimulate viral replication. J Virol 84, 2675-2686.

Gripon, P., Diot, C., Theze, N., Fourel, I., Loreal, O., Brechot, C. \& Guguen-Guillouzo, C. (1988). Hepatitis B virus infection of adult human hepatocytes cultured in the presence of dimethyl sulfoxide. J Virol 62, 4136-4143.

Gripon, P., Rumin, S., Urban, S., Le Seyec, J., Glaise, D., Cannie, I., Guyomard, C., Lucas, J., Trepo, C. \& Guguen-Guillouzo, C. (2002). Infection of a human hepatoma cell line by hepatitis B virus. Proc Natl Acad Sci U S A 99, 15655-15660.

Guo, W. T., Wang, J., Tam, G., Yen, T. S. \& Ou, J. S. (1991). Leaky transcription termination produces larger and smaller than genome size hepatitis $B$ virus $X$ gene transcripts. Virology 181, 630-636.

Heathcote, E. J., Marcellin, P., Buti, M., Gane, E., De Man, R. A., Krastev, Z., Germanidis, G., Lee, S. S., Flisiak, R., Kaita, K., Manns, M., Kotzev, I., Tchernev, K., Buggisch, P., Weilert, F., Kurdas, O. O., Shiffman, M. L., Trinh, H., Gurel, S., Snow-Lampart, A., Borroto-Esoda, K., Mondou, E., Anderson, J., Sorbel, J. \& Rousseau, F. (2011). Three-year efficacy and safety of tenofovir disoproxil fumarate treatment for chronic hepatitis B. Gastroenterology 140, 132-143.

Henkler, F., Hoare, J., Waseem, N., Goldin, R. D., McGarvey, M. J., Koshy, R. \& King, I. A. (2001). Intracellular localization of the hepatitis B virus HBx protein. J Gen Virol 82, 871-882.

Hirsch, R. C., Lavine, J. E., Chang, L. J., Varmus, H. E. \& Ganem, D. (1990). Polymerase gene products of hepatitis B viruses are required for genomic RNA packaging as wel as for reverse transcription. Nature 344, 552-555.

Hoare, J., Henkler, F., Dowling, J. J., Errington, W., Goldin, R. D., Fish, D. \& McGarvey, M. J. (2001). Subcellular localisation of the X protein in HBV infected hepatocytes. J Med Virol 64, 419-426.

Hu, Z., Zhang, Z., Doo, E., Coux, O., Goldberg, A. L. \& Liang, T. J. (1999). Hepatitis B virus X protein is both a substrate and a potential inhibitor of the proteasome complex. $\mathrm{J}$ Virol 73, 7231-7240.

Junker-Niepmann, M., Bartenschlager, R. \& Schaller, H. (1990). A short cis-acting sequence is required for hepatitis $\mathrm{B}$ virus pregenome encapsidation and sufficient for packaging of foreign RNA. EMBO J 9, 3389-3396.

Karayiannis, P. (2003). Hepatitis B virus: old, new and future approaches to antiviral treatment. J Antimicrob Chemother 51, 761-785.

Keasler, V. V., Hodgson, A. J., Madden, C. R. \& Slagle, B. L. (2007). Enhancement of hepatitis B virus replication by the regulatory $X$ protein in vitro and in vivo. J Virol 81, 2656-2662.

Keasler, V. V., Hodgson, A. J., Madden, C. R. \& Slagle, B. L. (2009). Hepatitis B virus HBx protein localized to the nucleus restores $\mathrm{HBx}$-deficient virus replication in HepG2 cells and in vivo in hydrodynamically-injected mice. Virology 390, 122-129. 
Kim, J. H., Sohn, S. Y., Benedict Yen, T. S. \& Ahn, B. Y. (2008). Ubiquitin-dependent and independent proteasomal degradation of hepatitis B virus $X$ protein. Biochem Biophys Res Commun 366, 1036-1042.

Klein, N. P., Bouchard, M. J., Wang, L. H., Kobarg, C. \& Schneider, R. J. (1999). Src kinases involved in hepatitis B virus replication. EMBO J 18, 5019-5027.

Knaus, T. \& Nassal, M. (1993). The encapsidation signal on the hepatitis B virus RNA pregenome forms a stem-loop structure that is critical for its function. Nucleic Acids Res 21, 3967-3975.

Kott, N., König, A., Glebe, D. (2010). Hepatitis B virus (HBV) bypasses classical endocytic pathways to infect primary hepatocytes in vitro. Journal of Hepatology 52, S48-S49.

Leistner, C. M., Gruen-Bernhard, S. \& Glebe, D. (2008). Role of glycosaminoglycans for binding and infection of hepatitis B virus. Cell Microbiol 10, 122-133.

Leupin, O., Bontron, S., Schaeffer, C. \& Strubin, M. (2005). Hepatitis B virus X protein stimulates viral genome replication via a DDB1-dependent pathway distinct from that leading to cell death. J Virol 79, 4238-4245.

Liaw, Y. F., Sung, J. J., Chow, W. C., Farrell, G., Lee, C. Z., Yuen, H., Tanwandee, T., Tao, Q. M., Shue, K., Keene, O. N., Dixon, J. S., Gray, D. F. \& Sabbat, J. (2004). Lamivudine for patients with chronic hepatitis B and advanced liver disease. N Engl J Med 351, 1521-1531.

Lucifora, J., Arzberger, S., Durantel, D., Belloni, L., Strubin, M., Levrero, M., Zoulim, F., Hantz, O. \& Protzer, U. (2011). Hepatitis B Virus X protein is essential to initiate and maintain virus replication after infection. J Hepatol. 2011 55, 996-1003.

Marcellin, P., Bonino, F., Lau, G. K., Farci, P., Yurdaydin, C., Piratvisuth, T., Jin, R., Gurel, S., Lu, Z. M., Wu, J., Popescu, M. \& Hadziyannis, S. (2009). Sustained response of hepatitis $\mathrm{B}$ e antigen-negative patients 3 years after treatment with peginterferon alpha-2a. Gastroenterology 136, 2169-2179 e2161-2164.

Melegari, M., Wolf, S. K. \& Schneider, R. J. (2005). Hepatitis B virus DNA replication is coordinated by core protein serine phosphorylation and HBx expression. J Virol 79, 9810-9820.

Moucari, R., Korevaar, A., Lada, O., Martinot-Peignoux, M., Boyer, N., Mackiewicz, V., Dauvergne, A., Cardoso, A. C., Asselah, T., Nicolas-Chanoine, M. H., Vidaud, M., Valla, D., Bedossa, P. \& Marcellin, P. (2009). High rates of HBsAg seroconversion in HBeAg-positive chronic hepatitis B patients responding to interferon: a long-term follow-up study. J Hepatol 50, 1084-1092.

Nassal, M. (1992). The arginine-rich domain of the hepatitis B virus core protein is required for pregenome encapsidation and productive viral positive-strand DNA synthesis but not for virus assembly. J Virol 66, 4107-4116.

Nordlund, P. \& Reichard, P. (2006). Ribonucleotide reductases. Annu Rev Biochem 75, 681-706.

Patient, R., Hourioux, C. \& Roingeard, P. (2009). Morphogenesis of hepatitis B virus and its subviral envelope particles. Cell Microbiol 11, 1561-1570.

Pollicino, T., Belloni, L., Raffa, G., Pediconi, N., Squadrito, G., Raimondo, G. \& Levrero, M. (2006). Hepatitis B virus replication is regulated by the acetylation status of hepatitis $B$ virus cccDNA-bound $\mathrm{H} 3$ and $\mathrm{H} 4$ histones. Gastroenterology 130, 823-837.

Porterfield, J. Z., Dhason, M. S., Loeb, D. D., Nassal, M., Stray, S. J. \& Zlotnick, A. (2010). Full-length hepatitis $B$ virus core protein packages viral and heterologous RNA with similarly high levels of cooperativity. J Virol 84, 7174-7184. 
Quasdorff, M. \& Protzer, U. (2010). Control of hepatitis B virus at the level of transcription. J Viral Hepat 17, 527-536.

Rabe, B., Glebe, D. \& Kann, M. (2006). Lipid-mediated introduction of hepatitis B virus capsids into nonsusceptible cells allows highly efficient replication and facilitates the study of early infection events. J Virol 80, 5465-5473.

Reifenberg, K., Nusser, P., Lohler, J., Spindler, G., Kuhn, C., von Weizsacker, F. \& Kock, J. (2002). Virus replication and virion export in X-deficient hepatitis B virus transgenic mice. J Gen Virol 83, 991-996.

Schek, N., Bartenschlager, R., Kuhn, C. \& Schaller, H. (1991). Phosphorylation and rapid turnover of hepatitis B virus X-protein expressed in HepG2 cells from a recombinant vaccinia virus. Oncogene 6, 1735-1744.

Schulze-Bergkamen, H., Untergasser, A., Dax, A., Vogel, H., Buchler, P., Klar, E., Lehnert, T., Friess, H., Buchler, M. W., Kirschfink, M., Stremmel, W., Krammer, P. H., Muller, M. \& Protzer, U. (2003). Primary human hepatocytes--a valuable tool for investigation of apoptosis and hepatitis B virus infection. J Hepatol 38, 736-744.

Schulze, A., Gripon, P. \& Urban, S. (2007). Hepatitis B virus infection initiates with a large surface protein-dependent binding to heparan sulfate proteoglycans. Hepatology 46, 1759-1768.

Sirma, H., Weil, R., Rosmorduc, O., Urban, S., Israel, A., Kremsdorf, D. \& Brechot, C. (1998). Cytosol is the prime compartment of hepatitis B virus $\mathrm{X}$ protein where it colocalizes with the proteasome. Oncogene 16, 2051-2063.

Sitterlin, D., Bergametti, F., Tiollais, P., Tennant, B. C. \& Transy, C. (2000). Correct binding of viral $X$ protein to UVDDB-p127 cellular protein is critical for efficient infection by hepatitis B viruses. Oncogene 19, 4427-4431.

Sprinzl, M. F., Oberwinkler, H., Schaller, H. \& Protzer, U. (2001). Transfer of hepatitis B virus genome by adenovirus vectors into cultured cells and mice: crossing the species barrier. J Virol 75, 5108-5118.

Stoeckl, L., Funk, A., Kopitzki, A., Brandenburg, B., Oess, S., Will, H., Sirma, H. \& Hildt, E. (2006). Identification of a structural motif crucial for infectivity of hepatitis B viruses. Proc Natl Acad Sci U S A 103, 6730-6734.

Su, Q., Schroder, C. H., Hofmann, W. J., Otto, G., Pichlmayr, R. \& Bannasch, P. (1998). Expression of hepatitis $B$ virus $X$ protein in HBV-infected human livers and hepatocellular carcinomas. Hepatology 27, 1109-1120.

Summers, J., Smith, P. M. \& Horwich, A. L. (1990). Hepadnavirus envelope proteins regulate covalently closed circular DNA amplification. J Virol 64, 2819-2824.

Tang, H., Delgermaa, L., Huang, F., Oishi, N., Liu, L., He, F., Zhao, L. \& Murakami, S. (2005). The transcriptional transactivation function of $\mathrm{HBx}$ protein is important for its augmentation role in hepatitis B virus replication. J Virol 79, 5548-5556.

Tsuge, M., Hiraga, N., Akiyama, R., Tanaka, S., Matsushita, M., Mitsui, F., Abe, H., Kitamura, S., Hatakeyama, T., Kimura, T., Miki, D., Mori, N., Imamura, M., Takahashi, S., Hayes, C. N. \& Chayama, K. (2010). HBx protein is indispensable for development of viraemia in human hepatocyte chimeric mice. J Gen Virol 91, 1854-1864.

Urban, S., Hildt, E., Eckerskorn, C., Sirma, H., Kekule, A. \& Hofschneider, P. H. (1997). Isolation and molecular characterization of hepatitis $\mathrm{B}$ virus $\mathrm{X}$-protein from a baculovirus expression system. Hepatology 26, 1045-1053.

van Bommel, F., de Man, R. A., Wedemeyer, H., Deterding, K., Petersen, J., Buggisch, P., Erhardt, A., Huppe, D., Stein, K., Trojan, J., Sarrazin, C., Bocher, W. O., Spengler, 
U., Wasmuth, H. E., Reinders, J. G., Moller, B., Rhode, P., Feucht, H. H., Wiedenmann, B. \& Berg, T. (2010). Long-term efficacy of tenofovir monotherapy for hepatitis B virus-monoinfected patients after failure of nucleoside/nucleotide analogues. Hepatology 51, 73-80.

Visvanathan, K., Skinner, N. A., Thompson, A. J., Riordan, S. M., Sozzi, V., Edwards, R., Rodgers, S., Kurtovic, J., Chang, J., Lewin, S., Desmond, P. \& Locarnini, S. (2007). Regulation of Toll-like receptor-2 expression in chronic hepatitis B by the precore protein. Hepatology 45, 102-110.

Walter, E., Keist, R., Niederost, B., Pult, I. \& Blum, H. E. (1996). Hepatitis B virus infection of tupaia hepatocytes in vitro and in vivo. Hepatology 24, 1-5.

Wang, H. P. \& Rogler, C. E. (1991). Topoisomerase I-mediated integration of hepadnavirus DNA in vitro. J Virol 65, 2381-2392.

Wei, Y., Neuveut, C., Tiollais, P. \& Buendia, M. A. (2010). Molecular biology of the hepatitis $B$ virus and role of the $X$ gene. Pathol Biol (Paris) 58, 267-272.

Weil, R., Sirma, H., Giannini, C., Kremsdorf, D., Bessia, C., Dargemont, C., Brechot, C. \& Israel, A. (1999). Direct association and nuclear import of the hepatitis B virus X protein with the NF-kappaB inhibitor IkappaBalpha. Mol Cell Biol 19, 6345-6354.

Wieland, S., Thimme, R., Purcell, R. H. \& Chisari, F. V. (2004). Genomic analysis of the host response to hepatitis B virus infection. Proc Natl Acad Sci U S A 101, 6669-6674.

Wu, H. L., Chen, P. J., Lin, M. H. \& Chen, D. S. (1991). Temporal aspects of major viral transcript expression in Hep G2 cells transfected with cloned hepatitis B virus DNA: with emphasis on the $X$ transcript. Virology 185, 644-651.

Xu, Z., Yen, T. S., Wu, L., Madden, C. R., Tan, W., Slagle, B. L. \& Ou, J. H. (2002). Enhancement of hepatitis $\mathrm{B}$ virus replication by its $\mathrm{X}$ protein in transgenic mice. $\mathrm{J}$ Virol 76, 2579-2584.

Yen, T. S. (1996). Hepadnaviral X Protein:Review of Recent Progress. J Biomed Sci 3, 20-30.

Zhang, Z., Protzer, U., Hu, Z., Jacob, J. \& Liang, T. J. (2004). Inhibition of cellular proteasome activities enhances hepadnavirus replication in an HBX-dependent manner. J Virol $78,4566-4572$.

Zhang, Z., Sun, E., Ou, J. H. \& Liang, T. J. (2010). Inhibition of cellular proteasome activities mediates HBX-independent hepatitis B virus replication in vivo. J Virol 84, 93269331.

Zhang, Z., Torii, N., Furusaka, A., Malayaman, N., Hu, Z. \& Liang, T. J. (2000). Structural and functional characterization of interaction between hepatitis $B$ virus $X$ protein and the proteasome complex. J Biol Chem 275, 15157-15165.

Zhang, Z., Torii, N., Hu, Z., Jacob, J. \& Liang, T. J. (2001). X-deficient woodchuck hepatitis virus mutants behave like attenuated viruses and induce protective immunity in vivo. J Clin Invest 108, 1523-1531.

Zlotnick, A., Johnson, J. M., Wingfield, P. W., Stahl, S. J. \& Endres, D. (1999). A theoretical model successfully identifies features of hepatitis B virus capsid assembly. Biochemistry 38, 14644-14652.

Zoulim, F., Lucifora, J. (2006). Hepatitis B virus and drug resistance: implications for treatment. Future Virology 1, 361-376.

Zoulim, F., Saputelli, J. \& Seeger, C. (1994). Woodchuck hepatitis virus X protein is required for viral infection in vivo. J Virol 68, 2026-2030. 


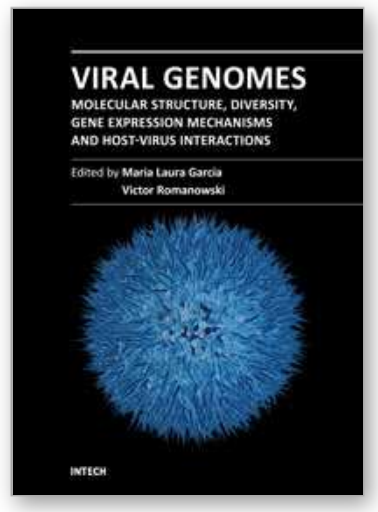

\author{
Viral Genomes - Molecular Structure, Diversity, Gene Expression \\ Mechanisms and Host-Virus Interactions \\ Edited by Prof. Maria Garcia
}

ISBN 978-953-51-0098-0

Hard cover, 302 pages

Publisher InTech

Published online 24, February, 2012

Published in print edition February, 2012

Viruses are small infectious agents that can replicate only inside the living cells of susceptible organisms. The understanding of the molecular events underlying the infectious process has been of central interest to improve strategies aimed at combating viral diseases of medical, veterinary and agricultural importance. Some of the viruses cause dreadful diseases, while others are also of interest as tools for gene transduction and expression and in non-poluting insect pest management strategies. The contributions in this book provide the reader with a perspective on the wide spectrum of virus-host systems. They are organized in sections based on the major topics covered: viral genomes organization, regulation of replication and gene expression, genome diversity and evolution, virus-host interactions, including clinically relevant features. The chapters also cover a wide range of technical approaches, including high throughput methods to assess genome variation or stability. This book should appeal to all those interested in fundamental and applied aspects of virology.

\title{
How to reference
}

In order to correctly reference this scholarly work, feel free to copy and paste the following:

Julie Lucifora and Ulrike Protzer (2012). Hepatitis B Virus X Protein: A Key Regulator of the Virus Life Cycle, Viral Genomes - Molecular Structure, Diversity, Gene Expression Mechanisms and Host-Virus Interactions, Prof. Maria Garcia (Ed.), ISBN: 978-953-51-0098-0, InTech, Available from:

http://www.intechopen.com/books/viral-genomes-molecular-structure-diversity-gene-expression-mechanismsand-host-virus-interactions/hepatitis-b-virus-x-protein-a-key-regulator-of-the-virus-life-cycle

\section{INTECH}

open science | open minds

\section{InTech Europe}

University Campus STeP Ri

Slavka Krautzeka 83/A

51000 Rijeka, Croatia

Phone: +385 (51) 770447

Fax: +385 (51) 686166

www.intechopen.com

\section{InTech China}

Unit 405, Office Block, Hotel Equatorial Shanghai

No.65, Yan An Road (West), Shanghai, 200040, China

中国上海市延安西路65号上海国际贵都大饭店办公楼 405 单元

Phone: +86-21-62489820

Fax: $+86-21-62489821$ 
(C) 2012 The Author(s). Licensee IntechOpen. This is an open access article distributed under the terms of the Creative Commons Attribution 3.0 License, which permits unrestricted use, distribution, and reproduction in any medium, provided the original work is properly cited. 